\title{
X-ray tomography of cryopreserved human prostate cancer cells: mitochondrial targeting by an organoiridium photosensitiser
}

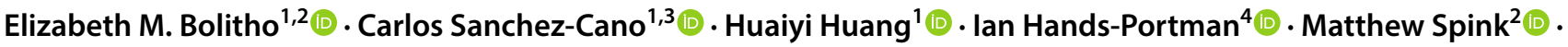

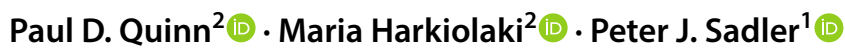

Received: 12 December 2019 / Accepted: 4 February 2020 / Published online: 2 March 2020

(C) The Author(s) 2020

\begin{abstract}
The organoiridium complex $\operatorname{Ir}\left[(\mathrm{C}, \mathrm{N})_{2}(\mathrm{O}, \mathrm{O})\right](\mathbf{1})$ where $\mathrm{C}, \mathrm{N}=1$-phenylisoquinoline and $\mathrm{O}, \mathrm{O}=2,2,6,6$-tetramethyl-3,5-heptanedionate is a promising photosensitiser for Photo-Dynamic Therapy (PDT). 1 is not toxic to cells in the dark. However, irradiation of the compound with one-photon blue or two-photon red light generates high levels of singlet oxygen $\left({ }^{1} \mathrm{O}_{2}\right)$ (in Zhang et al. Angew Chem Int Ed Engl 56 (47):14898-14902 https://doi.org/10.1002/anie.201709082,2017), both within cell monolayers and in tumour models. Moreover, photo-excited 1 oxidises key proteins, causing metabolic alterations in cancer cells with potent antiproliferative activity. Here, the tomograms obtained by cryo-Soft X-ray Tomography (cryo-SXT) of human PC3 prostate cancer cells treated with 1, irradiated with blue light, and cryopreserved to maintain them in their native state, reveal that irradiation causes extensive and specific alterations to mitochondria, but not other cellular components. Such new insights into the effect of ${ }^{1} \mathrm{O}_{2}$ generation during PDT using iridium photosensitisers on cells contribute to a detailed understanding of their cellular mode of action.
\end{abstract}

\section{Graphic abstract}

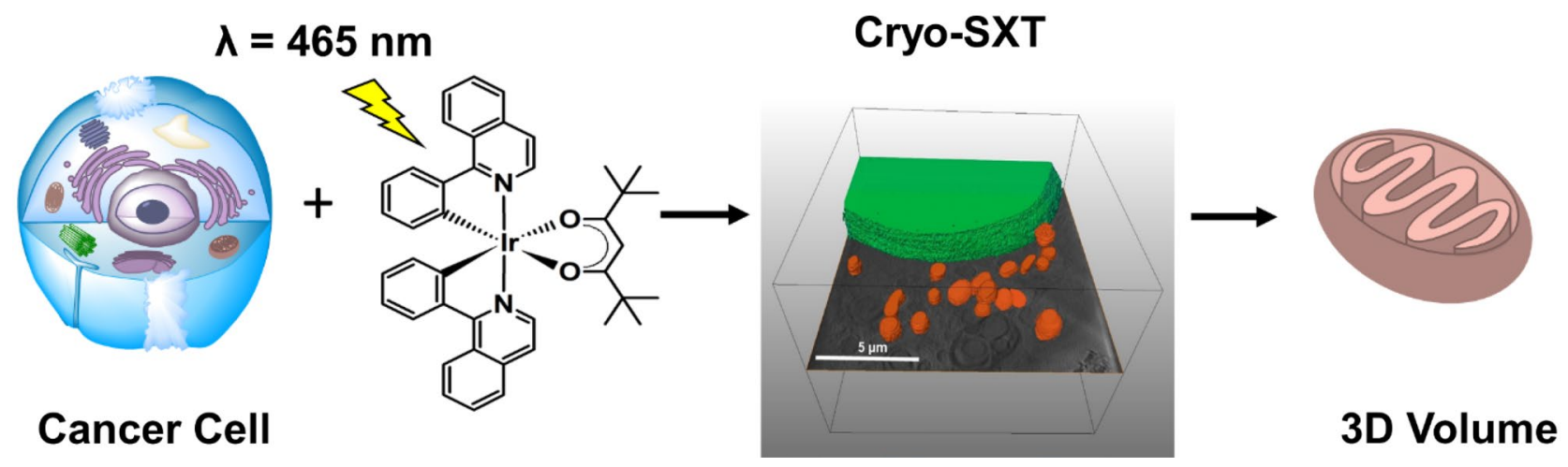

Keywords Photodynamic therapy $\cdot$ Iridium complexes $\cdot$ Phosphorescence $\cdot$ Anticancer metallodrugs $\cdot$ Cryo-soft X-ray tomography $\cdot \mathrm{X}$-ray microscopy

\section{Abbreviations}

AuNP Gold nanoparticle fiducials

Cryo-SXT Cryo-soft X-ray tomography

Cryo-TXM Cryo-transmission X-ray microscope

Electronic supplementary material The online version of this article (https://doi.org/10.1007/s00775-020-01761-8) contains supplementary material, which is available to authorized users.

Extended author information available on the last page of the article

$\begin{array}{ll}\text { DMSO } & \text { Dimethylsulfoxide } \\ \text { GFP } & \text { Green fluorescent protein } \\ \text { IC }_{50} & \text { Half-maximal inhibitory concentration } \\ \text { PBS } & \text { Phosphate-buffered saline } \\ \text { PC3 } & \text { Human prostate cancer cells } \\ \text { PDT } & \text { Photodynamic therapy } \\ \text { ROS } & \text { Reactive oxygen species } \\ \text { ROI } & \text { Region of interest } \\ \text { RPMI } & \text { Roswell Park Memorial Institute }\end{array}$


SuRVoS Super region volume segmentation

TEM Transmission electron microscopy

\section{Introduction}

Photodynamic Therapy (PDT) is a non-invasive therapeutic approach used to treat surface cancers. It uses spatially directed visible light $(\lambda=500-800 \mathrm{~nm})$ to irradiate a photosensitiser prodrug, which is non-toxic in the dark [2-7]. This generates reactive oxygen species (ROS) - particularly singlet oxygen $\left({ }^{1} \mathrm{O}_{2}\right)$-in a highly confined manner within the irradiated area, subsequently inducing apoptosis locally in the tumour [8-10]. As such, PDT can help to reduce unwanted side effects normally experienced by patients treated with other chemotherapeutic agents [11].

Cyclometallated organoiridium(III) octahedral complexes are promising photosensitisers for PDT [12-22]. They possess high photostability and long luminescence lifetimes, together with an ability to permeate cells [23], and generate toxic ROS upon irradiation. In particular, the organoiridium complex $\operatorname{Ir}\left[(\mathrm{C}, \mathrm{N})_{2}(\mathrm{O}, \mathrm{O})\right](\mathbf{1})(\mathrm{C}, \mathrm{N}=1$-phenylisoquinoline and $\mathrm{O}, \mathrm{O}=2,2,6,6$-tetramethyl-3,5-heptanedionate, Fig. 1) and its analogues have shown outstanding biological properties. Complex 1 has a long phosphorescent lifetime $\left(\lambda_{\mathrm{ex}}=458 \mathrm{~nm} ; \lambda_{\mathrm{p}}=620 \mathrm{~nm} ; \tau_{\mathrm{p}}=59 \mathrm{~ns}\right)$ in the presence of oxygen [1], and exerts potent antiproliferative activity after one- or two-photon activation with low doses of visible light [1]. This generates high amounts of highly toxic singlet oxygen $\left({ }^{1} \mathrm{O}_{2}\right)$ and causes profound oxidative damage to proteins important for cell metabolism (i.e. histidine residues on aldose reductase and heat-shock protein-70, HsP-70) [1].

Notably, the oxidative stress triggered by irradiating cells treated with 1 increases the expression of enzymes of the glycolytic pathway [1], apparently suggesting a higher

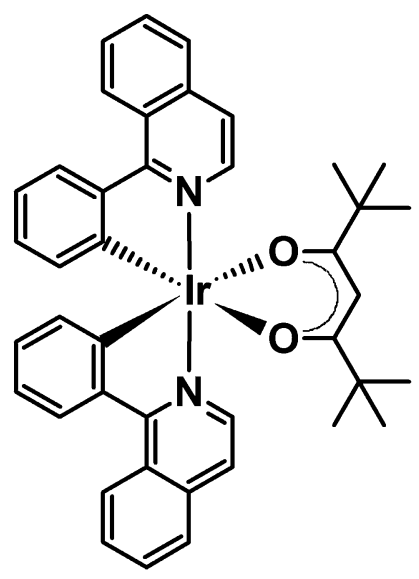

Fig. 1 Structure of $\left[\operatorname{Ir}(\mathrm{C}, \mathrm{N})_{2}(\mathrm{O}, \mathrm{O})\right][1]$ (where $\mathrm{C}, \mathrm{N}=1$-phenylisoquinoline and $\mathrm{O}, \mathrm{O}=2,2,6,6$-tetramethyl-3,5-heptanedionate) [1] dependency of the cells on the glucose metabolism. Thus, 1 might cause alterations in mitochondrial activity leading to depletion of the metabolism involving these organelles. Structural information at a sub-cellular level on the effects caused by the irradiation of cells treated with $\mathbf{1}$ can make an important contribution towards our understanding of the mechanism of anticancer activity of this family of PDT photosensitisers. Furthermore, mitochondria have been proposed previously as major target sites for a variety of other iridium photosensitisers [16, 18, 19, 24], so there is wider interest in developing methods which allow the direct investigation of the effects of photo-irradiation of such complexes on cellular organelles.

Cryo-Soft X-ray Tomography (cryo-SXT) is an X-raybased technique which operates at the 'water-window' (spectral region between the $\mathrm{K}$ edges of carbon and oxygen atoms, ca $280-530 \mathrm{eV}$, where structured carbon-rich biological matter absorbs light significantly more than the surrounding oxygen-rich medium) [25]. This generates natural contrast and allows imaging of the inner structure of cryopreserved whole cells without the need for further contrast through the use of additional chemical staining [26]. Cryo-SXT makes use of samples that have been vitrified, to immobilise and cryo-preserve cell structure, and therefore delivers 3D imaging of hydrated biological samples (cells and thin tissue slices) under near-native conditions at high resolution (in the tens of nanometre range) [27, 28]. This provides detailed in situ structural information on the distribution and morphology of cell organelles [29, 30]. Hence, this technique has the potential to provide remarkable insights into the changes induced upon the exposure of cells to activated metallodrug candidates [31]. Here, we have used cryo-SXT at the biological cryo-imaging beamline B24 of the UK synchrotron, Diamond Light Source, to probe the effects of the photoactivation of $\mathbf{1}$ on the cellular organelles of human PC3 prostate cancer cells.[32]

\section{Materials and methods}

\section{Materials}

200 mesh gold TEM F1finder grids with an R2/2 quantifoil carbon substrate were purchased from Quantifoil Micro Tools GmbH (Germany). Gold nanoparticle fiducials (AuNP) of $250 \mathrm{~nm}$ diameter were purchased from BBI Solutions (UK). MitoTracker Red FM 580 (excitation/emission $=581 / 644 \mathrm{~nm}$ ) was purchased from Fischer Scientific (UK). Molecular-grade DMSO (Bioultra, GC $\geq 99.5 \%$ ) was purchased from Sigma Aldrich (UK). RPMI-1640 (nonphenol red) culture medium supplemented with penicilin/ streptomycin, L-glutamine and Fetal bovine serum (details in SI) was supplied by the Media Preparation Service in 
the School of Life Sciences (University of Warwick). PC3 human prostate adenocarcinoma cells (Catalogue Number 90112714) were purchased from the European Collection of Cell Cultures (ECACC). Cells were tested every 6 months to confirm mycoplasma-free status.

\section{Synthesis of 1}

$\left[\operatorname{Ir}(\mathrm{C}, \mathrm{N})_{2}(\mathrm{O}, \mathrm{O})\right](\mathbf{1})$ was synthesised and fully characterised following previously reported methods [1].

\section{Growth of PC3 cells on quantifoil TEM Grids}

Quantifoil F1 TEM grids (3.05 mm diameter) were deposited in 24-well tissue culture plates (Greiner Bio-One, UK; $1 \mathrm{grid} /$ well) and irradiated with UV-light for $20 \mathrm{~min}$ to sterilise. PC3 human prostate cancer cells were seeded on the grids $\left(1 \times 10^{5}\right.$ cells $/ \mathrm{mL} ; 2 \mathrm{~mL} /$ well $)$ and incubated for $24 \mathrm{~h}$ $\left(37^{\circ} \mathrm{C}, 5 \% \mathrm{CO}_{2}\right)$ in RPMI-1640 cell culture medium (supplemented with $10 \%$ fetal bovine serum, $1 \%$ penicillin/ streptomycin and $1 \%$ L-glutamine $(2 \mathrm{mM}))$. After $24 \mathrm{~h}$, the medium was removed, and cells were treated with 0 or $1 \mu \mathrm{M}$ of 1 (1/6th of the half-maximal inhibitory concentration, $\mathrm{IC}_{50}$; prepared in 5\% DMSO, 95\% non-phenol red RPMI1640) for $2 \mathrm{~h}$ in the dark. The supernatant was removed after incubation and replaced with fresh RPMI-1640 medium. Cells were then incubated for $10 \mathrm{~min}$ at room temperature under either (a) dark conditions (no light exposure) or (b) irradiation with blue light $\left(465 \mathrm{~nm}, 4.8 \mathrm{~mW} / \mathrm{cm}^{2}\right)$, followed by further incubation for $24 \mathrm{~h}$ in the dark $\left(37^{\circ} \mathrm{C}, 5 \% \mathrm{CO}_{2}\right)$. After this, Mitotracker Red FM $\left(\lambda_{\text {ex/em }}=581 / 644 \mathrm{~nm}\right)$ was added to a final concentration of $1 \mathrm{nM}$ to all samples for $15 \mathrm{~min}$. The supernatant was thereafter removed and cells were washed with PBS $(\times 2)$, gold nanoparticle fiducials added (ca. $3.6 \times 10^{7}$ particles in $10 \mu \mathrm{L}$ ), blotted with filter paper ( $1 \mathrm{~s}$ ) to remove the excess liquid, and plunge-frozen in liquid propane:ethane mixture (cooled in liquid nitrogen). The resulting vitrified samples were stored under liquid nitrogen vapour phase for further analysis and imaging.

\section{Cryo-SXT experiment}

All cryo-SXT imaging was performed on an UltraXRMS220C (Carl Zeiss X-ray Microscopy, Inc) at beamline B24 at Diamond Light Source (Didcot, UK).

First, fluorescence imaging of MitoTracker Red $\left(\lambda_{\mathrm{ex} / \mathrm{em}}=581 / 644 \mathrm{~nm}\right)$ distribution was used to locate mitochondria on the cryo-preserved grids using optical microscopy (50X) on an Axioimager M2 (Zeiss) coupled to a CMS196M LED cryo-correlative stage (Linkam Scientific Instruments Ltd). This allowed identification of suitable cell candidates for cryo-SXT analysis (vitrified whole cells on intact grid surfaces without ice contamination). Mapped samples (brightfield and fluorescence imaging) were then transferred to the X-ray microscope, under cryogenic conditions (vitrified status was maintained throughout sample transfer and data collection). Initial 2D inspection of whole grid squares was achieved by forming image mosaics of consecutive regions in areas of interest (using single field of view size of $\left.16 \times 16 \mu \mathrm{m}^{2}\right)$ collected with brief exposure to soft X-rays $(0.5 \mathrm{~s}, 500 \mathrm{eV})$ and detected in continuous mode using a CCD camera (Pixis, XO 1024B; Princeton Scientific). Selected areas were placed on the microscope stage's centre of rotation through tracking gold nanoparticle fiducials or other dense cell features (i.e. lipid droplets) between tilt angles -30 and $+30^{\circ}$ and imaging focus to the desired depth in the cells was adjusted by moving the $40 \mathrm{~nm}$ zone plate objective. Tilt series of images of areas of interest were acquired using a $-65^{\circ}$ to $+65^{\circ}$ sample tilt (total rotation: $130^{\circ}$ ) at $0.5^{\circ}$ rotation steps. Depending on sample thickness, different exposure times were required to collect tomograms from PC3 cancer cells: (i) Untreated control (Dark) $=6 \mathrm{~s}$ (at high tilt angles) and $3 \mathrm{~s}$ (at low tilt, $\left.0^{\circ}\right)$; (ii) Untreated control $(465 \mathrm{~nm})=2 \mathrm{~s}$ (high tilt) and $1 \mathrm{~s}$ (low tilt); (iii) 1 (Dark) $=4 \mathrm{~s}$ (high tilt) and $2 \mathrm{~s}$ (low tilt); (iv) $1(465 \mathrm{~nm})=8 \mathrm{~s}$ (high tilt) and $4 \mathrm{~s}$ (low tilt). This relates to the attenuation of X-rays due to variable thickness of samples (influenced by cell density and size, as well as solution content adjacent to target areas).

\section{Tomogram reconstruction}

Raw tilt series data (.tiff files) were reconstructed using IMOD software (which contained the eTomo and $3 \mathrm{dmod}$ tools) [33, 34]. The files were converted from tiff to MRC format and the following reconstruction settings were used: pixel size $=15.8 \mathrm{~nm}$, fiducial diameter $=250 \mathrm{~nm}$, image rotation $=0^{\circ}$, starting angle $=-65^{\circ}$, increment step $=0.5^{\circ}$. The raw image stack was viewed before creating the command scripts to identify views to exclude in the tomogram reconstruction. Then, an X-ray model and a 'fixed stack' (which creates a secondary stack with the X-rays removed) were generated. Cross-correlation of still images was calculated with a high-frequency cut off radius of 0.1. Coarse-aligned stacks and fiducial models were generated automatically for each tomogram; fiducials incorrectly assigned by the software were removed and any unassigned fiducials were added manually for all angles and views. Tilt series were then fine-aligned relative to adjacent views with global variation settings of no rotation and fixed magnification of 1 . The requested tomogram depth was 1000 (binning $=3$ ). Boundary models were generated and cropped to contain cellular information only. The final aligned stacks were then generated from the calculated $z$-axis and pitch angles using linear interpolation, producing tomograms with no positional drifts. Reconstructed tomograms were generated in $3 \mathrm{dmod}$ 
$[33,34]$ and post-processed to remove unwanted information (noise or background), saved as reconstruction files ready for analysis by SuRVoS [35].

\section{Segmentation}

The reconstructed tomograms (.rec) were processed using SuRVoS [35]. The region of interest (ROI) was selected appropriately for each tomogram by deleting specific angle views in which thick ice or gridlines obstructed the view. A Gaussian filter feature channel was used and supervoxels $(\mathrm{SP}=8 \times 8 \times 8)$ were generated in Gaussian mode. Mitochondria annotations were added by manually selecting mitochondrial regions in the supervoxels setting; the mitochondria were located automatically by the software and corrected manually every five to ten views. For each tomogram, 15-30 mitochondria were selected and analysed. From this, the average mitochondrial volume $\left(\mu \mathrm{m}^{3}\right)$ was calculated for each PC3 cell tomogram under the specified conditions. Additionally, the nucleus was segmented. The exported files were visualised in Amira (Avizo 2016) [36] software using the volume-rendering and ortho slice settings to generate images and videos of each reconstructed and segmented tomograms.

\section{Results and discussion}

Prostate cancer is the most common cancer in men (with over 1 million reported cases in 2013) [37, 38] and a strong candidate for treatment using PDT $[32,39]$. We probed the effect of the photoactivation of $\mathbf{1}$ on the mitochondria, and other organelles, of PC3 human prostate cancer cells. This complex was used as a racemic mixture, and although the enantiomers may be recognised differently by transport systems and other biomolecules, chirality is not expected to affect the photosensitisation properties of $\mathbf{1}$ such as the generation of singlet oxygen. As expected, the complex was not toxic to PC3 cells under dark conditions $\left(\mathrm{IC}_{50}>50 \mu \mathrm{M}\right)$, but showed potent antiproliferative activity $\left(\mathrm{IC}_{50}: 6 \pm 1 \mu \mathrm{M}\right)$ when cells were treated with 1 for $2 \mathrm{~h}$ followed by blue light irradiation (10 min $\lambda_{\text {irr }}: 465 \mathrm{~nm}, 4.8 \mathrm{~mW} / \mathrm{cm}^{2}$; cells left to recover for $46 \mathrm{~h}$ before assay). Also, irradiation of untreated cells with blue light under the same conditions did not have any effect on their proliferation. Using this information, we generated vitrified samples of PC3 cells treated with 1 $\left(1 \mu \mathrm{M} ; 1 / 6\right.$ th $\left.\mathrm{IC}_{50}\right)$ and exposed to dark (non-toxic) or irradiated (blue light) conditions, and stained with MitoTracker Red for cryo-SXT.

Suitable cell candidates for X-ray analysis were initially selected by mapping the grids at $77 \mathrm{~K}$ (following brightfield, and mitotracker red using the YFP filter; Fig. S1-S4) on a cryogenic optical microscope. Faint green fluorescence was observed in cells treated with 1 when irradiated with blue light (465 nm) and using a microscopy filter designed for GFP $\left(\lambda_{\text {ex/em }}=488 / 510 \mathrm{~nm}\right.$; Fig. S4). This signal can be attributed to the tail of the phosphorescence emission band of the complex, as $\mathbf{1}$ shows deep-red emission upon irradiation with light of a similar wavelength $\left(\lambda_{\mathrm{ex}}=458 \mathrm{~nm}\right.$; $\lambda_{\mathrm{p}}=620 \mathrm{~nm}$ ) [1]. Samples and controls were then loaded into the autosampler chamber at B24 and maintained in cryogenic conditions throughout all data collection.

We used soft X-rays $(500 \mathrm{eV})$ focused to a $40 \times 40 \mathrm{~nm}^{2}$ spot size to collect fast mosaic maps of the grid squares. This allowed localisation of PC3 cells previously identified using fluorescence microscopy (Fig. 2a). Remarkably, samples treated with the Ir complex 1 showed increased X-ray absorption, requiring longer exposure times at high tilt angles even when control samples were covered by thicker ice layers (i.e. $6 \mathrm{~s}$ for untreated control cell in dark compared to $8 \mathrm{~s}$ for cells treated with 1 upon blue light irradiation). The need for this increase is likely due to the concentrations of highly electron-dense iridium complex within the cells. Nevertheless, it was possible to collect clear X-ray projection images from all samples. These images permitted clear observation of the cellular and nuclear membranes, the nucleus, and the nucleolus. Moreover, they also allowed identification of a large number of cytoplasmic vesicles and organelles such as mitochondria (Fig. 2b, Fig. S1-S4).

Cells were further studied using cryo-SXT. A total of ten X-ray tomograms (T1-T10; Fig. 2c, Fig. S5-S14; Videos SV1-SV10) were collected from $16 \times 16 \mu \mathrm{m}^{2}$ regions of interest in cells untreated or treated with $1 \mu \mathrm{M}$ of $\mathbf{1}$, either kept in the dark, or irradiated with blue light (10 $\min \lambda_{\text {irr: }}$ : $465 \mathrm{~nm}, 4.8 \mathrm{~mW} / \mathrm{cm}^{2}$ ). As expected, both irradiated and non-irradiated untreated PC3 cells possessed undamaged cellular membranes and nucleus, and showed large similarities in their cellular and organelle morphology (Fig. 3a, b, S5-S7; Videos SV1-SV3). In particular, mitochondria, distinguished from other vesicular organelles by the presence of cristae [41], were ellipsoid in shape and located close to the nucleus. Additionally, lamelipodia (flat cellular protrusions) [42] associated with a number of spherical vesicular structures were visible near the plasma membrane of the untreated cells (Fig. 3a, S5-S6; Videos SV1-SV2). Such accumulation may correspond to the shedding of membrane vesicles (i.e. exosomes and oncosomes) [43], a feature reported previously for PC3 cells [44-47]. Likewise, the morphology of cells treated with $1 \mu \mathrm{M}$ of 1 but not irradiated was closely related to that observed for untreated controls (both irradiated and non-irradiated). Tomograms of the latter showed well-structured nuclei, undamaged plasma membranes with vesicle-shedding and lamellopodia, and apparently healthy mitochondria with well-defined cristae (Fig. 3c, Fig. S8-S11; Videos SV4-SV7). Therefore, these results correlated with the lack of toxicity of $\mathbf{1}$ when cells 
(a)

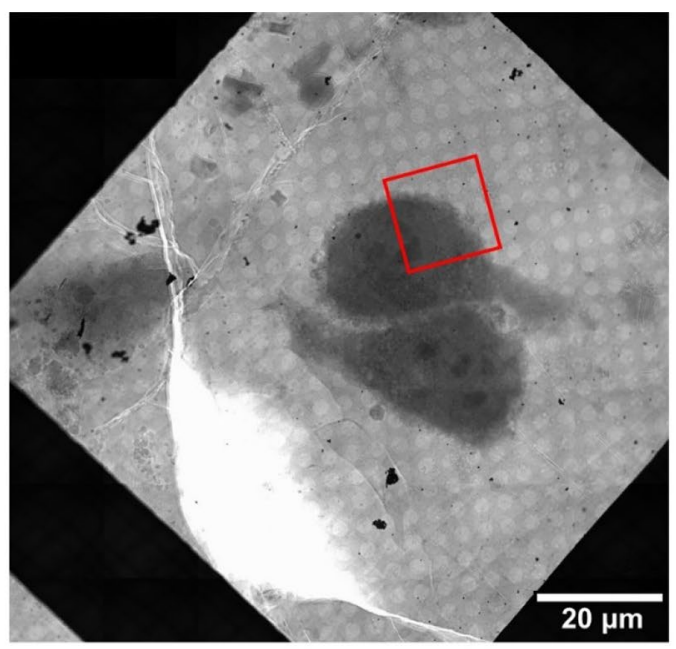

(c)

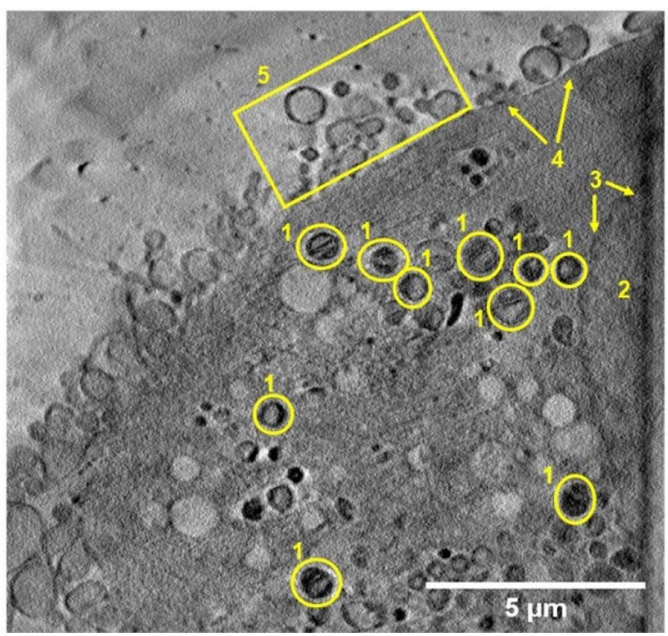

(b)

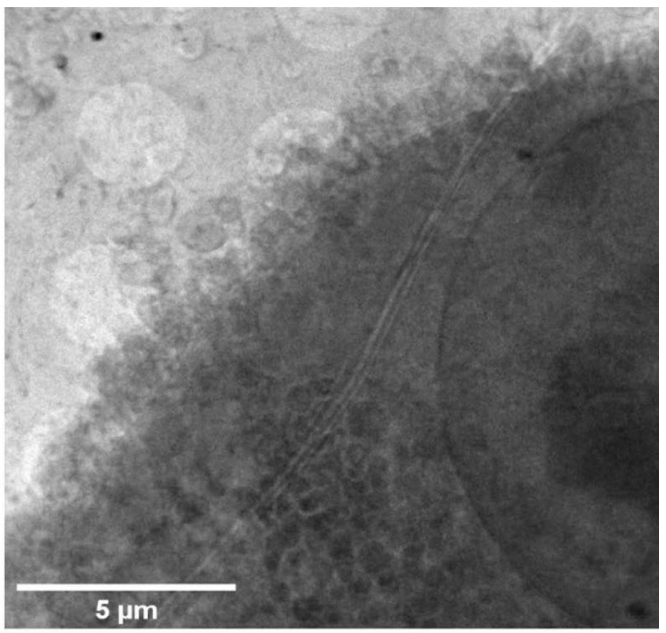

(d)

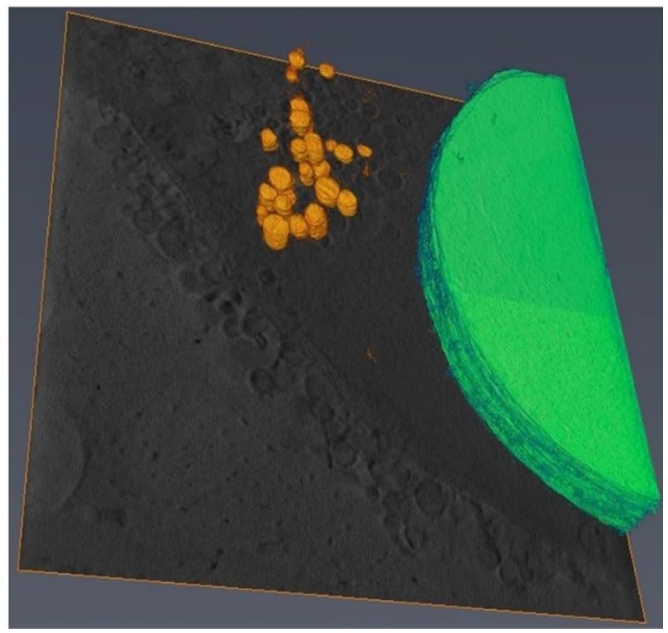

Fig. 2 Cryo-SXT images of cryogenically-fixed PC3 prostate cancer cells grown on carbon-gold TEM grids $(24 \mathrm{~h})$ and treated with $1 \mu \mathrm{M}$ of 1 for $2 \mathrm{~h}$, followed by $10 \mathrm{~min}$ irradiation with blue light $(\lambda=465 \mathrm{~nm})$ and $24 \mathrm{~h}$ recovery in complex-free medium: a X-ray mosaic image of a $100 \times 100 \mu \mathrm{m}^{2}$ area of the grid; $\mathbf{b}$ X-ray projection image collected from a $16 \times 16 \mu \mathrm{m}^{2}$ area of interest (marked as a red square) in a after exposure to soft x-rays $(8 \mathrm{~s}, 500 \mathrm{eV})$; c $2 \mathrm{D}$

were not irradiated, confirming that neither blue light nor treatment with complex 1 under dark conditions resulted in mitochondrial alterations.

On the contrary, heavily altered smaller mitochondria, and severe membrane blebbing, indicating initiation of a celldeath process [48], were visible when cells were treated with $1 \mu \mathrm{M} 1$ and irradiated with blue light (Figs. $2 \mathrm{~b}$ and $3 \mathrm{~d}$, Fig. S12-S14; Videos SV8-SV10). Segmentation of tomograms of the different samples using SuRVoS [35] allowed further morphological analysis. 3D volumes of the nuclei and a number of mitochondria from all samples were obtained, and results were visualised using the Amira 3D imaging software (Fig. 2d, Fig S15-S18; Videos SV11-SV14) [36]. The mitochondria in cells subjected to treatment with organo-iridium projection of the reconstructed tomogram obtained from the same area (in b); showing $1=$ mitochondria, $2=$ nucleus, $3=$ nuclear membrane, $4=$ plasma membrane, $5=$ vesicles; $\mathbf{d}$ 3D segmented tomogram analysed in SuRVoS and visualised in Amira; showing mitochondria (orange) and nucleus (green). Images were generated using ImageJ (a) [40], IMOD (b, c) $[33,34]$ and SuRVoS and Amira imaging softwares (d) $[34,36]$

complex 1 and irradiation were found to be a homogeneous population of small spherical organelles $(0.08 \pm 0.03$ $\mu \mathrm{m}^{3}, N=19$; range of volumes: $0.05-0.12 \mu \mathrm{m}^{3}$; Fig. 4, Fig. S18, Table S1; Video SV14). In contrast, untreated cells (both non-irradiated and irradiated) and cells treated with 1, but not exposed to blue light, contained larger and elongated mitochondria (untreated non-irradiated: $0.98 \pm 1.2$ $\mu \mathrm{m}^{3}, N=14$; untreated irradiated: $0.65 \pm 0.35 \mu \mathrm{m}^{3}, N=20$; $1 \mu \mathrm{M} 1$ non-irradiated: $0.77 \pm 0.38 \mu \mathrm{m}^{3}, N=26$; Fig. 4 , Fig. S15-S17, Table S1; Videos SV11-SV13), which were similar to organelles found normally in healthy cells (size from $0.75-3 \mu \mathrm{m}^{2}$ in length) [49].

The alterations observed in mitochondria of PC3 cells treated with 1 and irradiated must be caused by ${ }^{1} \mathrm{O}_{2}$ 
(a)

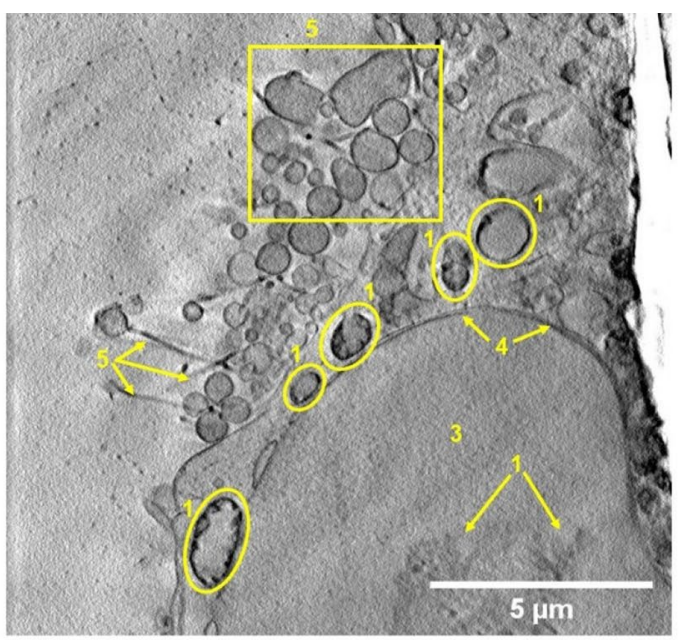

(c)

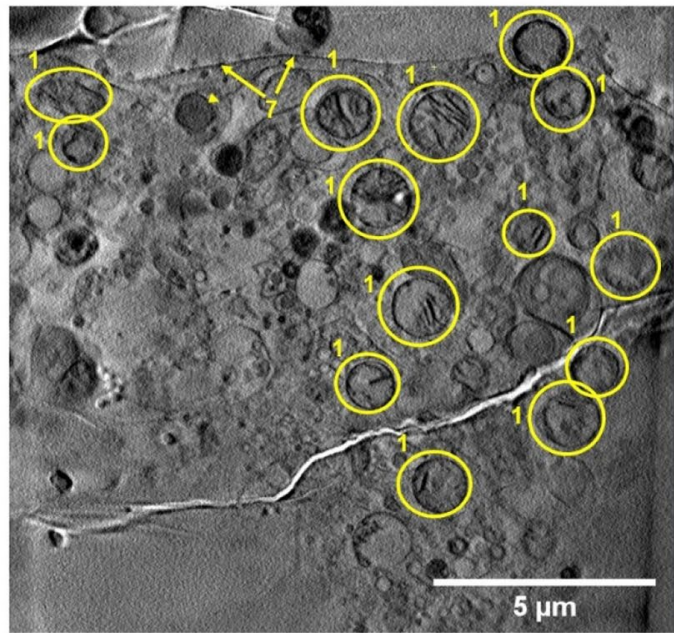

(b)

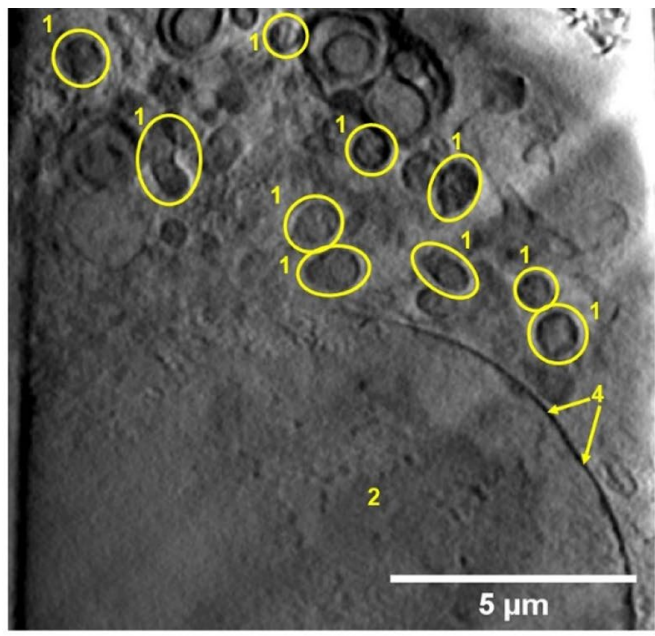

(d)

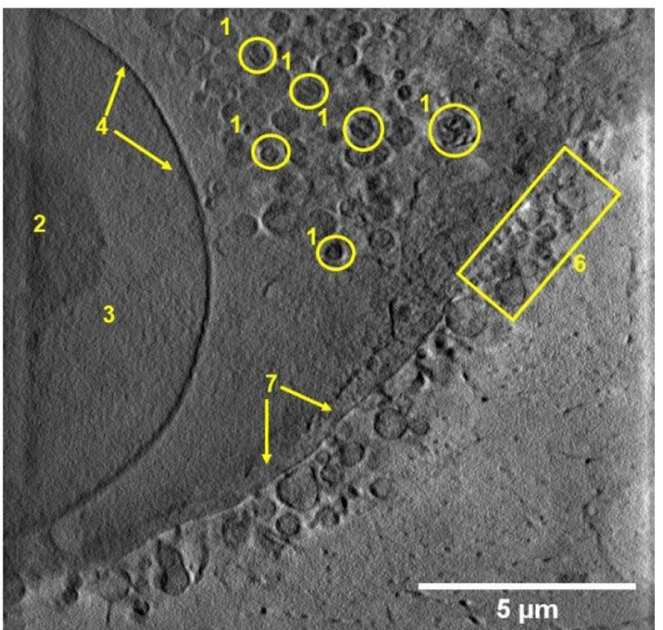

Fig. $32 \mathrm{D}$ projections of reconstructed X-ray tomograms $(16 \times 16$ $\mu \mathrm{m}^{2}$ ) of cryogenically fixed PC3 human prostate carcinoma cells grown on Quantifoil TEM grids showing changes in cellular and organelle morphology upon treatment with $\mathbf{1}$, followed by irradiation with blue light. a Untreated cells in dark conditions (not irradiated with blue light; $465 \mathrm{~nm}$ ). b Untreated cells exposed to blue light (10 min, $\left.465 \mathrm{~nm}, 4.8 \mathrm{~mW} / \mathrm{cm}^{2}\right)$. c Cells treated with $1(1 \mu \mathrm{M})$

generated by complex located within the proximity of the organelle, as singlet oxygen $\left({ }^{1} \mathrm{O}_{2}\right)$ is short lived $(<200 \mathrm{~ns}$ in vitro) [51, 52], possesses a low capacity to diffuse within the cell (up to $1 \mu \mathrm{m}$ ) [53-55], and is not accumulated inside them. Previous experiments using optical microscopy had shown that 1 was broadly distributed within the cytosol of cells [1]. Moreover, detailed analysis of mitochondria from non-irradiated cells treated similarly with $\mathbf{1}$ showed the presence of low-electron-density (light) areas in their interior, surrounded by darker external membranes and cristae (Figs. 3, 4). Ir accumulation within the mitochondria would make it harder for soft X-rays to penetrate, turning them darker in appearance. Therefore, it is unlikely that the complex is able to penetrate to the interior of mitochondria under normal circumstances. Thus, the dark nature of under dark conditions (not irradiated with blue light; $465 \mathrm{~nm}$ ). d Cells treated with $1(1 \mu \mathrm{M})$ for $2 \mathrm{~h}$, followed by exposure to blue light (10 min, $\left.465 \mathrm{~nm}, 4.8 \mathrm{mw} / \mathrm{cm}^{2}\right)$. Cellular features shown: $1=$ mitochondria, $2=$ nucleolus, $3=$ nucleus, $4=$ nuclear membrane, $5=$ features of lamellipodium, $6=$ spherical vesicles, $7=$ plasma membrane. Images were generated using IMOD software [33, 34]

mitochondria found in cells treated with $\mathbf{1}$ and irradiated might be due to an overall reduction in their size (condensing the outer membrane and internal cristae into a smaller volume).

\section{Conclusions}

We have used synchrotron soft X-ray tomography to study the effects of visible-light photoactivation of the organo iridium photosensitiser 1 on PC 3 human prostate cancer cells. The cells were cryopreserved after treatment to maintain them as close to their native state as possible. Dramatic morphological differences were observed between treatedirradiated (activated $\mathbf{1}$ at 1/6th $\mathrm{IC}_{50}$ ) and control cells. These 


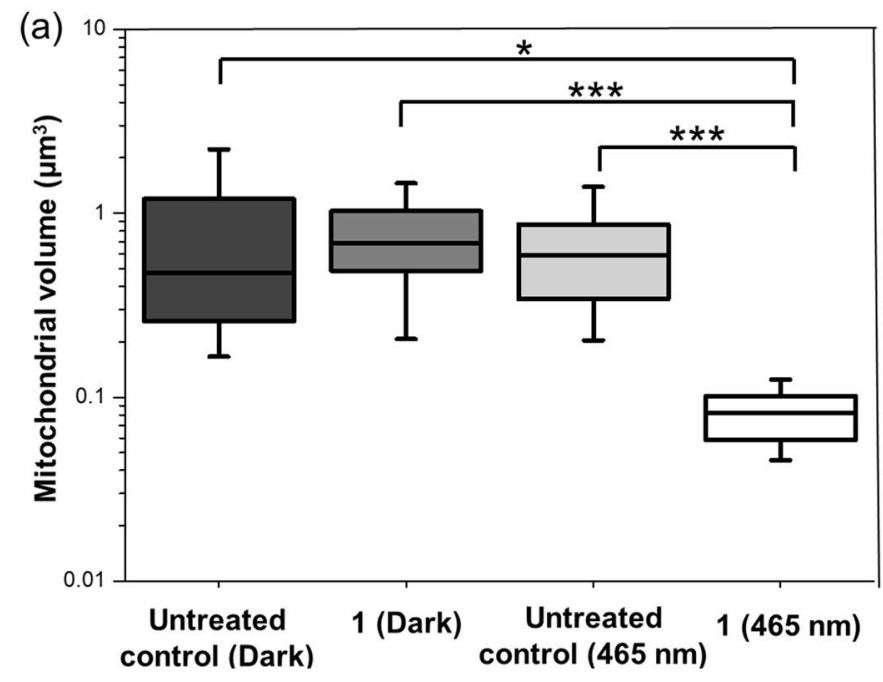

(b)
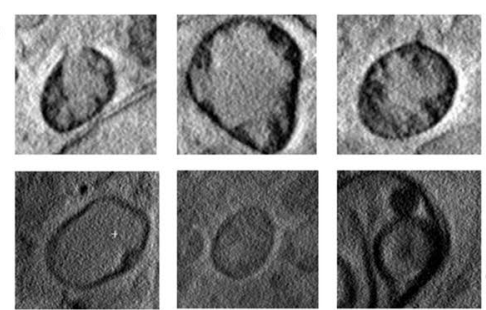

Untreated Control (Dark)
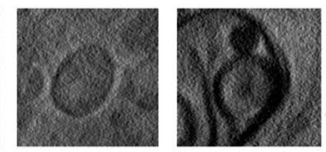

Untreated Control (465 nm)
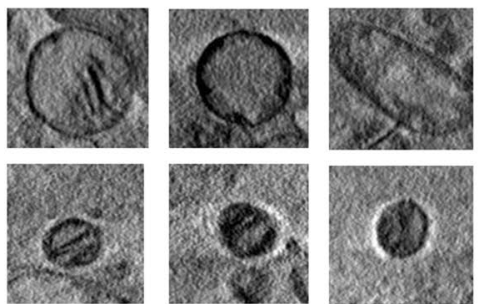

1 (Dark)

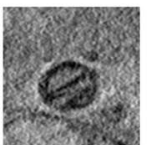

$1(465 \mathrm{~nm})$
Fig. 4 Changes in mitochondrial size and structure upon treatment of PC3 cells with 1 followed by irradiation with blue light. a Box and whisker plot showing average volumes $\left(\mu \mathrm{m}^{3}\right)$ of segmented mitochondria from cryogenically fixed $\mathrm{PC} 3$ prostate carcinoma cells untreated or treated with $1 \mu \mathrm{M}$ of $\mathbf{1}$ for $2 \mathrm{~h}$, exposed to $10 \mathrm{~min}$ of dark or blue light $(465 \mathrm{~nm})$, and followed by $24 \mathrm{~h}$ recovery in complexfree medium $\left(37{ }^{\circ} \mathrm{C}, 5 \% \mathrm{CO}_{2}\right)$. Statistical analysis was performed using Welch's unpaired $t$ test (assuming unequal variables; ${ }^{*} p<0.05$,

included apparent mitochondrial alterations, most likely induced by singlet oxygen generated upon irradiation of Ir complex within the proximity of these organelles. It is possible that increases in the levels of a number of enzymes in the glycolytic pathway observed previously upon treatment of cells with $\mathbf{1}$ followed by irradiation with blue light [1] might be linked to changes in mitochondrial physiology, although this requires further investigation. Overall, we have demonstrated that cryo-SXT can provide direct insights into the effects of PDT agents on organelles in cancer cells. Such experiments will enhance the development of new PDT photosensitisers, and accelerate their progression towards more advanced stages of clinical development.

Acknowledgements We thank CRUK/EPSRC (Grant No. C53561/ A19933), EPSRC (Grant No. EP/F034210/1) and Wellcome Trust (Grant No. 107691/Z/15/Z), Gipuzkoa Foru Aldundia (Gipuzkoa Fellows program for C.S.C), Maria de Maeztu Units of Excellence Program from the Spanish State Research Agency (MDM-2017-0720), Warwick Collaborative Postgraduate Research Scholarship and Diamond (studentship for E.M.B.) for financial support. We also thank J. P. C. Coverdale, H. E. Bridgewater and J. Song for assistance with tissue culture and cell experiments. Cryo-SXT tomograms were acquired in the frame of the Diamond proposals MX18339 and MX19615.

\section{Compliance with ethical standards}

Conflict of interest There are no conflicts to declare.
$* * p<0.01, * * * p<0.001)$. b Representative $2 \mathrm{D} 4 \times 4 \mu \mathrm{m}^{2}$ sections of X-ray tomograms showing mitochondria from cryogenically fixed PC3 prostate carcinoma cells untreated or treated with $1 \mu \mathrm{M}$ of 1 for $2 \mathrm{~h}$, exposed to $10 \mathrm{~min}$ of darkness or blue light $(465 \mathrm{~nm})$, and followed by $24 \mathrm{~h}$ recovery in complex-free media $\left(37{ }^{\circ} \mathrm{C}, 5 \% \mathrm{CO}_{2}\right)$. Images were generated using OriginPro 2018 (a) [50] and IMOD software (b) $[33,34]$

Open Access This article is licensed under a Creative Commons Attribution 4.0 International License, which permits use, sharing, adaptation, distribution and reproduction in any medium or format, as long as you give appropriate credit to the original author(s) and the source, provide a link to the Creative Commons licence, and indicate if changes were made. The images or other third party material in this article are included in the article's Creative Commons licence, unless indicated otherwise in a credit line to the material. If material is not included in the article's Creative Commons licence and your intended use is not permitted by statutory regulation or exceeds the permitted use, you will need to obtain permission directly from the copyright holder. To view a copy of this licence, visit http://creativecommons.org/licenses/by/4.0/.

\section{References}

1. Zhang P, Chiu CKC, Huang H, Lam YPY, Habtemariam A, Malcomson T, Paterson MJ, Clarkson GJ, O'Connor PB, Chao H, Sadler PJ (2017) Organoiridium photosensitizers induce specific oxidative attack on proteins within cancer cells. Angew Chem Int Ed Engl 56(47):14898-14902. https://doi.org/10.1002/anie.20170 9082

2. Yoon I, Li JZ, Shim YK (2013) Advance in photosensitizers and light delivery for photodynamic therapy. Clin Endosc 46(1):7-23. https://doi.org/10.5946/ce.2013.46.1.7

3. Agostinis P, Berg K, Cengel KA, Foster TH, Girotti AW, Gollnick SO, Hahn SM, Hamblin MR, Juzeniene A, Kessel D, Korbelik M, Moan J, Mroz P, Nowis D, Piette J, Wilson BC, Golab J (2011) Photodynamic therapy of cancer: an update. CA Cancer J Clin 61(4):250-281. https://doi.org/10.3322/caac.20114

4. Bonnet S (2018) Why develop photoactivated chemotherapy? Dalton Trans 47(31):10330-10343. https://doi.org/10.1039/C8DT0 $1585 \mathrm{~F}$ 
5. McFarland SA, Mandel A, Dumoulin-White R, Gasser G (2020) Metal-based photosensitizers for photodynamic therapy: the future of multimodal oncology? Curr Opin Chem Biol 56:23-27. https ://doi.org/10.1016/j.cbpa.2019.10.004

6. Gurruchaga-Pereda J, Martínez Á, Terenzi A, Salassa L (2019) Anticancer platinum agents and light. Inorg Chim Acta 495:118981. https://doi.org/10.1016/j.ica.2019.118981

7. Renfrew AK, Bryce NS, Hambley T (2015) Cobalt(III) chaperone complexes of curcumin: photoreduction, cellular accumulation and light-selective toxicity towards tumour cells. Chem Eur J 21(43):15224-15234. https://doi.org/10.1002/chem.201502702

8. Chekulayeva LV, Shevchuk IN, Chekulayev VA, Ilmarinen K (2006) Hydrogen peroxide, superoxide, and hydroxyl radicals are involved in the phototoxic action of hematoporphyrin derivative against tumor cells. J Environ Pathol Toxicol Oncol 25(1-2):51-77

9. Guo H, Qian H, Idris NM, Zhang Y (2010) Singlet oxygeninduced apoptosis of cancer cells using upconversion fluorescent nanoparticles as a carrier of photosensitizer. Nanomed-Nanotechnol 6(3):486-495. https://doi.org/10.1016/j.nano.2009.11.004

10. Huang H, Zhang P, Yu B, Jin C, Ji L, Chao H (2015) Synthesis, characterization and biological evaluation of mixed-ligand ruthenium(II) complexes for photodynamic therapy. Dalton Trans 44(39):17335-17345. https://doi.org/10.1039/C5DT02081F

11. Johnstone TC, Park GY, Lippard SJ (2014) Understanding and improving platinum anticancer drugs-phenanthriplatin. Anticancer Res 34(1):471-476

12. Huang H, Banerjee S, Qiu K, Zhang P, Blacque O, Malcomson T, Paterson MJ, Clarkson GJ, Staniforth M, Stavros VG, Gasser G, Chao H, Sadler PJ (2019) Targeted photoredox catalysis in cancer cells. Nat Chem 11(11):1041-1048. https://doi.org/10.1038/s4155 7-019-0328-4

13. Sudheesh KV, Jayaram PS, Samanta A, Bejoymohandas KS, Jayasree RS, Ajayaghosh A (2018) A cyclometalated Ir III complex as a lysosome-targeted photodynamic therapeutic agent for integrated imaging and therapy in cancer cells. Chem Eur J 24(43):10999-11007 https://doi.org/10.1002/chem.2018801918

14. Novohradsky V, Rovira A, Hally C, Galindo A, Vigueras G, Gandioso A, Svitelova M, Bresolí-Obach R, Kostrhunova H, Markova L, Kasparkova J, Nonell S, Ruiz J, Brabec V, Marchán V (2019) Towards novel photodynamic anticancer agents generating superoxide anion radicals: a cyclometalated IrIII complex conjugated to a far-red emitting coumarin. Angew Chem Int Ed Engl 58(19):6311-6315. https://doi.org/10.1002/anie.201901268

15. Wang L, Monro S, Cui P, Yin H, Liu B, Cameron C, Xu W, Hetu M, Fuller A, Kilina S, McFarland S, Sun W (2019) Heteroleptic Ir(III)N6 complexes with long-lived triplet excited states and in vitro photobiological activities. ACS Appl Mater Interfaces 11(4):3629-3644. https://doi.org/10.1021/acsami.8b14744

16. Zhang WY, Yi QY, Wang YJ, Du F, He M, Tang B, Wan D, Liu YJ, Huang HL (2018) Photoinduced anticancer activity studies of iridium(III) complexes targeting mitochondria and tubules. Eur J Med 151:568-584. https://doi.org/10.1016/j.ejmech.2018.04.013

17. Nam JS, Kang M-G, Kang J, Park S-Y, Lee SJC, Kim H-T, Seo JK, Kwon O-H, Lim MH, Rhee H-W, Kwon T-H (2016) Endoplasmic reticulum-localized iridium(III) complexes as efficient photodynamic therapy agents via protein modifications. J Am Chem Soc 138(34):10968-10977. https://doi.org/10.1021/jacs.6b05302

18. Lv W, Zhang Z, Zhang KY, Yang H, Liu S, Xu A, Guo S, Zhao Q, Huang W (2016) A mitochondria-targeted photosensitizer showing improved photodynamic therapy effects under hypoxia. A Angew Chem Int Ed Engl 55(34):9947-9951. https://doi. org/10.1002/anie.201604130

19. Venkatesh V, Berrocal-Martin R, Wedge CJ, Romero-Canelón I, Sanchez-Cano C, Song J-I, Coverdale JPC, Zhang P, Clarkson GJ, Habtemariam A, Magennis SW, Deeth RJ, Sadler PJ
(2017) Mitochondria-targeted spin-labelled luminescent iridium anticancer complexes. Chem Sci 8(12):8271-8278. https://doi. org/10.1039/C7SC03216A

20. Zamora A, Vigueras G, Rodríguez V, Santana MD, Ruiz J (2018) Cyclometalated iridium(III) luminescent complexes in therapy and phototherapy. Coord Chem 360:34-76. https://doi. org/10.1016/j.ccr.2018.01.010

21. Novohradsky V, Zamora A, Gandioso A, Brabec V, Ruiz J, Marchán V (2017) Somatostatin receptor-targeted organometallic iridium(III) complexes as novel theranostic agents. Chem Comm 53(40):5523-5526. https://doi.org/10.1039/C7CC01946G

22. Novohradsky V, Vigueras G, Pracharova J, Cutillas N, Janiak C, Kostrhunova H, Brabec V, Ruiz J, Kasparkova J (2019) Molecular superoxide radical photogeneration in cancer cells by dipyridophenazine iridium(III) complexes. Inorg Chem Front 6(9):2500 2513. https://doi.org/10.1039/C9QI00811J

23. Cao JJ, Tan CP, Chen MH, Wu N, Yao DY, Liu XG, Ji LN, Mao ZW (2017) Targeting cancer cell metabolism with mitochondria-immobilized phosphorescent cyclometalated iridium(III) complexes. Chem Sci 8(1):631-640. https://doi.org/10.1039/ c6sc02901a

24. Ma DL, Wu C, Wu KJ, Leung CH (2019) Iridium(III) complexes targeting apoptotic cell death in cancer cells. Molecules 24(15):E2739. https://doi.org/10.3390/molecules24152739

25. Berglund M, Rymell L, Peuker M, Wilhein T, Hertz HM (2000) Compact water-window transmission X-ray microscopy. J Microsc 197(Pt 3):268-273. https://doi.org/10.104 6/j.1365-2818.2000.00675.x

26. Teramoto T, Azai C, Terauchi K, Yoshimura M, Ohta T (2018) Soft X-ray imaging of cellular carbon and nitrogen distributions in heterocystous cyanobacteria. J Plant Physiol 177(1):52-61. https://doi.org/10.1104/pp.17.01767

27. Schneider G, Guttmann P, Heim S, Rehbein S, Mueller F, Nagashima K, Heymann JB, Müller WG, McNally JG (2010) Three-dimensional cellular ultrastructure resolved by X-ray microscopy. Nat Methods 7(12):985-987. https://doi. org/10.1038/nmeth.1533

28. Groen J, Conesa JJ, Valcárcel R, Pereiro E (2019) The cellular landscape by cryo soft X-ray tomography. Biophys Rev 11(4):611-619. https://doi.org/10.1007/s12551-019-00567-6

29. Fogelqvist E, Kördel M, Carannante V, Önfelt B, Hertz HM (2017) Laboratory cryo $\mathrm{x}$-ray microscopy for 3D cell imaging. Sci Rep 7(1):13433. https://doi.org/10.1038/s41598-017-13538 $-2$

30. Weston AE, Armer HEJ, Collinson LM (2009) Towards nativestate imaging in biological context in the electron microscope. J Chem Biol 3(3):101-112. https://doi.org/10.1007/s1215 4-009-0033-7

31. Conesa JJ, Carrasco AC, Rodríguez-Fanjul V, Yang Y, Carrascosa JL, Cloetens P, Pereiro E, Pizarro AM (2020) Unambiguous intracellular localization and quantification of a potent iridium anticancer compound by correlative $3 \mathrm{D}$ cryo $\mathrm{x}$-Ray imaging. Angew Chem Int Ed Engl. 59(3):1270-1278. https:// doi.org/10.1002/anie.201911510

32. Ferroni C, Del Rio A, Martini C, Manoni E, Varchi G (2019) Light-induced therapies for prostate cancer treatment. Front Chem 7:719. https://doi.org/10.3389/fchem.2019.00719

33. Mastronarde DN, Held SR (2017) Automated tilt series alignment and tomographic reconstruction in IMOD. J Struct Biol 197(2):102-113. https://doi.org/10.1016/j.jsb.2016.07.011

34. Kremer JR, Mastronarde DN, McIntosh JR (1996) Computer visualization of three-dimensional image data using IMOD. J Struct Biol 116(1):71-76. https://doi.org/10.1006/ jsbi.1996.0013

35. Luengo I, Darrow MC, Spink MC, Sun Y, Dai W, He CY, Chiu W, Pridmore T, Ashton AW, Duke EMH, Basham M, French 
AP (2017) SuRVoS: super-region volume segmentation workbench. J Struct Biol 198(1):43-53. https://doi.org/10.1016/j. jsb.2017.02.007

36. Mittag U, Kriechbaumer A, Rittweger J (2017) A novel interpolation approach for the generation of 3D-geometric digital bone models from image stacks. J Musculoskelet Neuronal Interact 17(2):86-96

37. Chen S-L, Wang S-C, Ho C-J, Kao Y-L, Hsieh T-Y, Chen W-J, Chen C-J, Wu P-R, Ko J-L, Lee H, Sung W-W (2017) Prostate cancer mortality-to-incidence ratios are associated with cancer care disparities in 35 countries. Sci Rep 7:40003. https://doi. org/10.1038/srep40003

38. Merriel SWD, May MT, Martin RM (2018) Predicting prostate cancer progression: protocol for a retrospective cohort study to identify prognostic factors for prostate cancer outcomes using routine primary care data. BMJ Open 8(1):e019409-e019409. https ://doi.org/10.1136/bmjopen-2017-019409

39. Gheewala T, Skwor T, Munirathinam G (2017) Photosensitizers in prostate cancer therapy. Oncotarget 8(18):30524-30538. https ://doi.org/10.18632/oncotarget.15496

40. Rueden CT, Schindelin J, Hiner MC, DeZonia BE, Walter AE, Arena ET, Eliceiri KW (2017) Image J2: ImageJ for the next generation of scientific image data. BMC Bioinform 18(1):529-529. https://doi.org/10.1186/s12859-017-1934-Z

41. Müller WG, Heymann JB, Nagashima K, Guttmann P, Werner S, Rehbein S, Schneider G, McNally JG (2012) Towards an atlas of mammalian cell ultrastructure by cryo soft X-ray tomography. J Struct Biol 177(2):179-192. https://doi.org/10.1016/j. jsb.2011.11.025

42. Geiger B, Yamada KM (2011) Molecular architecture and function of matrix adhesions. Cold Spring Harb Perspect Biol. https://doi. org/10.1101/cshperspect.a005033

43. Minciacchi VR, Freeman MR, Di Vizio D (2015) Extracellular vesicles in cancer: exosomes, microvesicles and the emerging role of large oncosomes. Semin Cell Dev Biol 40:41-51. https://doi. org/10.1016/j.semcdb.2015.02.010

44. Millimaggi D, Festuccia C, Angelucci A, D’Ascenzo S, Rucci N, Flati S, Bologna M, Teti A, Pavan A, Dolo V (2006) Osteoblastconditioned media stimulate membrane vesicle shedding in prostate cancer cells. Int J Oncol 28(4):909-914

45. Taylor DD, Black PH (1986) Shedding of plasma membrane fragments. Neoplastic and developmental importance. Dev Biol (NY 1985) 3:33-57

46. Dolo V, Adobati E, Canevari S, Assunta Picone M, Letizia Vittorelli M (1995) Dolo V, Adobati E, Canevari S, Picone MA,
Vittorelli MLMembrane vesicles shed into the extracellular medium by human breast carcinoma cells carry tumor-associated surface antigens. Clin Exp Metastasis 13:277-286. https://doi. org/10.1007/BF00133483

47. Albanese J, Meterissian S, Kontogiannea M, Dubreuil C, Hand A, Sorba S, Dainiak N (1998) Biologically active fas antigen and its cognate ligand are expressed on plasma membrane-derived extracellular vesicles. Blood 91(10):3862-3874

48. Janssen JJE, Grefte S, Keijer J, de Boer VCJ (2019) Mito-nuclear communication by mitochondrial metabolites and its regulation by B-vitamins. Front Physiol 10:78. https://doi.org/10.3389/fphys .2019 .00078

49. Wiemerslage L, Lee D (2016) Quantification of mitochondrial morphology in neurites of dopaminergic neurons using multiple parameters. J Neurosci Methods 262:56-65. https://doi. org/10.1016/j.jneumeth.2016.01.008

50. Moberly JG, Bernards MT, Waynant KV (2018) Key features and updates for origin 2018. J Cheminformatics 10(1):5. https://doi. org/10.1186/s13321-018-0259-x

51. Kramarenko GG, Hummel SG, Martin SM, Buettner GR (2006) Ascorbate reacts with singlet oxygen to produce hydrogen peroxide. Photochem Photobiol 82(6):1634-1637. https://doi. org/10.1111/j.1751-1097.2006.tb09823.x

52. Havrylyuk D, Heidary DK, Nease L, Parkin S, Glazer EC (2017) Photochemical properties and structure-activity relationships of $\mathrm{Ru}^{\mathrm{II}}$ complexes with pyridylbenzazole ligands as promising anticancer agents. Eur J Chem 12:1687-1694. https://doi.org/10.1002/ ejic. 201601450

53. Skovsen E, Snyder JW, Lambert JDC, Ogilby PR (2005) Lifetime and diffusion of singlet oxygen in a cell. J Phys Chem B 109(18):8570-8573. https://doi.org/10.1021/jp051163i

54. Kim S, Tachikawa T, Fujitsuka M, Majima T (2014) Far-red fluorescence probe for monitoring singlet oxygen during photodynamic therapy. J Am Chem Soc 136(33):11707-11715. https:// doi.org/10.1021/ja504279r

55. To T-L, Medzihradszky KF, Burlingame AL, DeGrado WF, Jo H, Shu X (2016) Photoactivatable protein labeling by singlet oxygen mediated reactions. Biorg Med Chem 26(14):3359-3363. https:// doi.org/10.1016/j.bmcl.2016.05.034

Publisher's Note Springer Nature remains neutral with regard to jurisdictional claims in published maps and institutional affiliations.

\section{Affiliations}

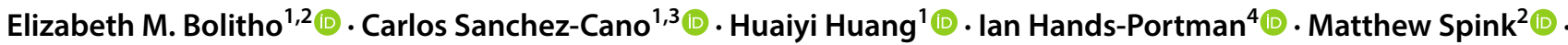 Paul D. Quinn ${ }^{2}$ (D) Maria Harkiolaki ${ }^{2}$. Peter J. Sadler ${ }^{1} \mathbb{C}$}

\author{
Carlos Sanchez-Cano \\ csanchez@cicbiomagune.es \\ Maria Harkiolaki \\ maria.harkiolaki@diamond.ac.uk \\ Peter J. Sadler \\ p.j.sadler@warwick.ac.uk
}

1 Department of Chemistry, University of Warwick, Gibbet Hill Road, Coventry CV4 7AL, UK
2 Diamond House, Harwell Science and Innovation Campus, Fermi Ave, Didcot OX11 0DE, UK

3 Center for Cooperative Research in Biomaterials (CIC biomaGUNE), Basque Research and Technology Alliance (BRTA), Paseo Miramon 182, 20014 Donostia-San Sebastián, Spain

4 School of Life Sciences, University of Warwick, Gibbet Hill Campus, Coventry CV4 7AL, UK 